\title{
MALDI-TOF mass spectrometry as a diagnostic tool in human and veterinary helminthology: a systematic review
}

\author{
Maureen Feucherolles ${ }^{1,2}$, Sven Poppert ${ }^{3,4}$, Jürg Utzinger ${ }^{3,4}$ (I) and Sören L. Becker ${ }^{1,3,4^{*}}$ (D)
}

\begin{abstract}
Background: Matrix-assisted laser desorption/ionization-time of flight (MALDI-TOF) mass spectrometry (MS) has become a widely used technique for the rapid and accurate identification of bacteria, mycobacteria and certain fungal pathogens in the clinical microbiology laboratory. Thus far, only few attempts have been made to apply the technique in clinical parasitology, particularly regarding helminth identification.

Methods: We systematically reviewed the scientific literature on studies pertaining to MALDI-TOF MS as a diagnostic technique for helminths (cestodes, nematodes and trematodes) of medical and veterinary importance. Readily available electronic databases (i.e. PubMed/MEDLINE, ScienceDirect, Cochrane Library, Web of Science and Google Scholar) were searched from inception to 10 October 2018, without restriction on year of publication or language. The titles and abstracts of studies were screened for eligibility by two independent reviewers. Relevant articles were read in full and included in the systematic review.
\end{abstract}

Results: A total of 84 peer-reviewed articles were considered for the final analysis. Most papers reported on the application of MALDI-TOF for the study of Caenorhabditis elegans, and the technique was primarily used for identification of specific proteins rather than entire pathogens. Since 2015, a small number of studies documented the successful use of MALDI-TOF MS for species-specific identification of nematodes of human and veterinary importance, such as Trichinella spp. and Dirofilaria spp. However, the quality of available data and the number of examined helminth samples was low.

Conclusions: Data on the use of MALDI-TOF MS for the diagnosis of helminths are scarce, but recent evidence suggests a potential role for a reliable identification of nematodes. Future research should explore the diagnostic accuracy of MALDI-TOF MS for identification of (i) adult helminths, larvae and eggs shed in faecal samples; and (ii) helminth-related proteins that are detectable in serum or body fluids of infected individuals.

Keywords: Diagnosis, Helminths, MALDI-TOF, Matrix-assisted laser desorption/ionization-time of flight, Neglected tropical diseases, Parasites

\section{Background}

In clinical and laboratory diagnostic settings, mass spectrometry (MS) has been utilized for several decades as an approach for protein-centred analysis of samples in medical chemistry $[1,2]$ and haematology laboratories [3]. In

\footnotetext{
*Correspondence: soeren.becker@uks.eu

${ }^{1}$ Institute of Medical Microbiology and Hygiene, Saarland University,

Homburg/Saar, Germany

Full list of author information is available at the end of the article
}

1975, Anhalt \& Fenselau [4] proposed, for the first time, the modification of matrix-assisted laser desorption/ionization time-of-flight (MALDI-TOF) MS as a method to characterize bacteria. Indeed, it was demonstrated that different bacterial species show specific protein mass spectra, which can be used for rapid identification.

During the past decade, MALDI-TOF MS has been widely introduced as a diagnostic technique in microbiology laboratories, where it has replaced most other tools (e.g. phenotypic tests, biochemical identification and 
agglutination kits) as the first-line pathogen identification method due to its high diagnostic accuracy, robustness, reliability and rapid turn-around time [5]. MALDI-TOF MS is now routinely employed for identification of bacteria [5-8], mycobacteria [5, 9] and some fungi [8]. More recently, MALDI-TOF MS has been applied in research settings for the detection and identification of viruses [10], protozoans and arthropods [11, 12]. In clinical practice, a specific quantity is brought on a target plate (e.g. culture-grown pathogen). Next, the target plate is pre-treated with a chemical reagent (so-called matrix, e.g. $\alpha$-cyano-4-hydroxycinnamic acid) and subjected to a mass spectrometer for further analysis. The MALDITOF apparatus, which is commercially available through different manufacturers [13, 14], uses laser to disperse and ionize the analyte into different molecules, which move through a vacuum driven by an electric field before reaching a detector membrane. The time-of-flight of the various molecules depends on their mass and their electric charge. The specific time-of-flight data are assembled, resulting in specific spectra that are compared to a commercial database, which allows for a rapid identification of the infectious agent and diagnostic accuracy, the latter of which is usually expressed as a score.

MALDI-TOF MS has several strengths if compared to other diagnostic tools, such as polymerase chain reaction (PCR) assays. Once the mass spectrometer and the corresponding databases are available in a laboratory, individual pathogen identification is inexpensive, and the sample preparation procedure does neither require highly skilled technicians nor complex additional laboratory infrastructure. Of note, MALDI-TOF MS is considerably less prone to contamination and results are available within a few minutes. However, constant power supply is a prerequisite, which limits the suitability of the technique in resource-constrained settings. Yet, it should be noted that MALDI-TOF MS is no longer restricted to highincome countries as it is increasingly available in reference laboratories in sub-Saharan Africa and elsewhere [15-19].

MALDI-TOF does not always require culture-grown colonies of a given pathogen. Instead, it can also be employed to identify microorganisms directly from positive blood culture broths [6] with high diagnostic accuracy [7]. Recently, Yang et al. [20] proposed a new framework to analyse MALDI-TOF spectra of bacterial mixtures (instead of only a single pathogen) and to directly characterize each component without purification procedures. Hence, this procedure might become available to be employed directly on other body fluids (e.g. urine, respiratory specimens and faecal samples), which would further increase its relevance in clinical practice $[21,22]$.
In contrast to clinical bacteriology, little research has been carried out pertaining to the application of MALDITOF MS for identification of parasites of human or veterinary importance [23]. Several studies utilized the technique on protozoan parasites such as Leishmania spp. [24-26], Giardia spp. [27], Cryptosporidium spp. [28], Trypanosoma spp. [29], Plasmodium spp. [30-32] and Dientamoeba spp. [33]. These studies used pre-treatment with ethanol and acetonitrile before subjecting the whole pathogens to MALDI-TOF analysis. Additionally, the technique has been used for identification of ectoparasites and vectors, such as ticks [34-37], fleas [38-41] and mosquitoes [42-49]. In contrast to the experiments on protozoans, only selected parts of the ectoparasites and vectors (e.g. legs, thoraxes or wings) were used and subjected to the same extraction method. A further novel approach to apply MALDI-TOF MS in clinical parasitology is the identification of specific serum peptides that are detectable in parasite-infected individuals [50].

Helminth infections caused by nematodes (e.g. Ascaris lumbricoides, hookworm, Strongyloides stercoralis and Trichuris trichiura), cestodes (e.g. Taenia spp.) and trematodes (e.g. Fasciola spp. and Schistosoma spp.) account for a considerable global burden of disease and are among the most common infections in marginalized populations in the tropics and subtropics [51]. Indeed, according to estimates put forth by the Global Burden of Disease (GBD) Study, 3.35 million disability-adjusted life years (DALYs) were attributable to intestinal nematode infections and schistosomiasis in 2017 [52].

Diagnosis is pivotal for effective treatment but requires at least a basic laboratory infrastructure, light microscopes and well-trained laboratory technicians who might not be available in remote areas of tropical and subtropical countries. In high-resource settings, in contrast, knowledge on microscopic identification of helminths is waning in many laboratories. It is surprising that the potential applicability of MALDI-TOF MS as a diagnostic tool for helminths of human and veterinary importance has not yet been systematically assessed, in particular because the technique has been successfully employed for identification of nematode plant pathogens [53-58]. Hence, the goal of this systematic review was to summarize the available data on MALDI-TOF MS application for diagnosis of helminths of medical and veterinary importance, and to provide recommendations for future research needs.

\section{Methods}

\section{Search strategy}

A systematic literature review was performed to identify all relevant scientific studies pertaining to MALDI-TOF MS as a diagnostic identification technique in medical 
and/or veterinary helminthology. The research was performed according to the guidance expressed in the Preferred Reporting Items for Systematic Reviews and Meta-Analyses (PRISMA) Statement [59].

The following electronic databases were systematically searched: MEDLINE/PubMed, ScienceDirect-Embase, Cochrane Library, Web of Science and Google Scholar. All studies published from inception to 10 October 2018 were eligible for inclusion without language restrictions. The bibliographies of all eligible documents were hand-searched for additional references. Conference abstracts or book chapters detected through these databases and additional library searches were also considered. The search strategy comprised keywords related to the MALDI-TOF MS technique (e.g. "MALDI-TOF" and "matrix-assisted laser desorption/ionization time-offlight") and helminthology (e.g. "helminth", "nematode", "cestode" and "trematode"). The full search strategies for every database are provided in Additional file 1 and the PRISMA checklist in Additional file 2.

\section{Eligibility screening}

After the systematic literature search, all duplicates were removed. Titles and abstracts of potentially eligible studies were screened to identify manuscripts relevant to the research question. Scientific reports on helminths of either plants or insects as well as studies on symbiotic bacteria of helminths were excluded for this review. However, we kept all publications related to the soil nematode Caenorhabditis elegans, as it is used as a model organism for biomedical research. Additionally, studies pertaining to MALDI-TOF/ TOF tandem MS were excluded, as this is a different modification of the MALDI-TOF MS technique, which is not routinely employed in clinical microbiology laboratories, but rather in research laboratory use for accurate characterization or sequencing of components like amino acids, metabolites, saccharides, etc. [60-62].

\section{Data extraction and analysis}

The literature search was performed by the first author of this manuscript (MF). All titles and abstracts were then independently reviewed by the first and the last author (MF and SLB) for inclusion and any disagreement was discussed until consensus was reached. All extracted manuscripts were analysed using a reference manager software (Mendeley; http://www.mendeley.com).

\section{Results}

Search results, number and year of publication of eligible studies

The search procedure and results obtained are shown in Fig. 1. In brief, the initial literature search yielded
329 published studies, with an additional two abstracts identified through further search. Following removal of 142 duplicates, a total of 189 articles were assessed in more detail, of which 66 studies were excluded based on the analysis of the respective titles and abstracts. A full-text analysis was carried out on the remaining 123 studies; 39 articles were finally excluded because their scope was outside the current research question. Hence, 84 articles were included, and these were published between 1997 and 2018. Figure 2 shows the number of publications, stratified by year of publication. The heterogeneity of data reported in the articles precluded any meaningful meta-analysis (Additional file 3).

\section{Specific applications of MALDI-TOF MS}

The first two manuscripts published in 1997 described structural analyses of glycosphingolipids found in Ascaris suum and C. elegans [63, 64]. Indeed, 95\% of all eligible studies used MALDI-TOF MS for identification of specific components rather than for the identification of entire pathogens (Fig. 2). It was only in 2015 when a report on MALDI-TOF MS as diagnostic tool for direct identification of Dirofilaria spp. became available [65]. Soon thereafter followed a proof-of-concept study utilizing MALDI-TOF MS for identification and differentiation of Trichinella spp. and some narrative reviews mentioning the lack of data on MALDITOF in helminthology [32, 66, 67]. Yet, most studies focused on distinct analyses of specific components, such as peptides [66-86], proteins [69, 87-114], lipids $[61,62,115-124]$, carbohydrates [125-143] and nucleic acids [144] in a research context. Hence, MALDI-TOF was mainly applied to study and compare the proteome or the peptidome of different helminth species, and most reports focused on C. elegans. For example, Husson et al. [74] employed a new approach combining liquid chromatography with MALDI-TOF MS to map and differentiate the neuropeptide profiles of C. elegans and the closely related species $C$. briggsae.

The two studies aiming at an identification of entire pathogens provided evidence that MALDI-TOF MS could reliably differentiate between species within the genus Trichinella [67] and Dirofilaria [65], respectively. In the study by Mayer-Scholl et al. [67], nine species and three genotypes of Trichinella isolated from mice, domestic pigs, wild boars and guinea pigs were utilized to create an in-house database with 27 raw spectra generated per specimen. All tested isolates could be distinguished with high diagnostic accuracy. The study by Pshenichnaya et al. [65], which had only been published as a conference abstract, investigated five Dirofilaria repens and five D. immitis specimens, the causative agents of human and 


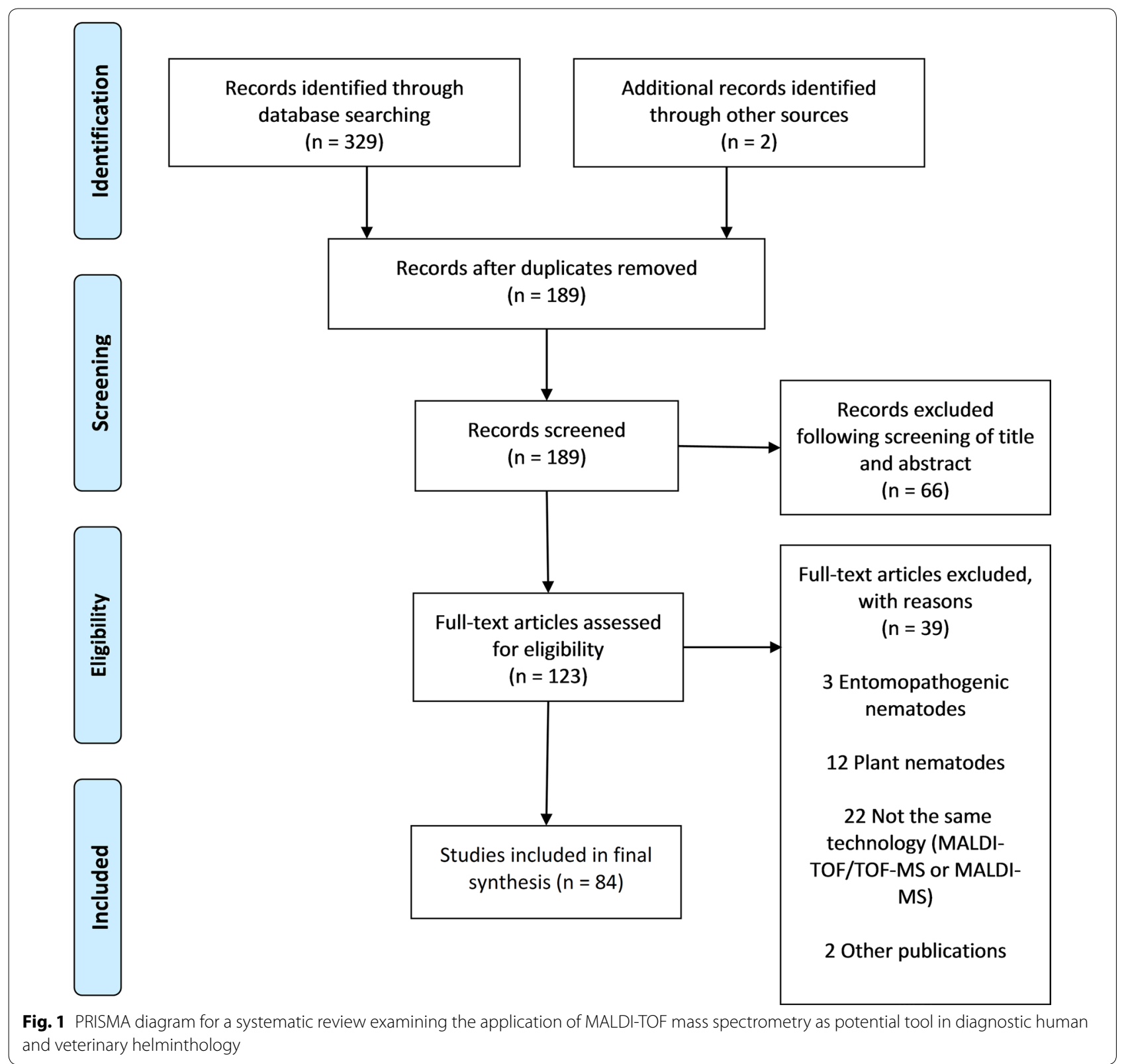

veterinary dirofilariasis, and reported that these could be well differentiated by MALDI-TOF MS. However, data were limited regarding the origin of the study samples, the quality of the spectra obtained by MALDI-TOF and the repeatability of the results. Yet, during the revision of this systematic review, Pshenichnaya et al. [145] published their work on dirofilariasis in a peer-reviewed journal and provided also data for two different species of Ascaris (i.e. A. suum and A. lumbricoides). These helminths could be differentiated by MALDI-TOF based on specific peaks and protein spectra patterns after a cell lysis using the Sepsityper Kit 50 (Bruker Daltonics; Bremen,
Germany) and a protein extraction with $70 \%$ formic acid and acetonitrile. However, this study has several limitations, and it remains unclear whether calibration steps or assessments of the repeatability and reproducibility of the analyses were performed. An additional paper, published in 2017, reported on MALDI-TOF MS application for cyathostomin helminths, a very diverse group of intestinal parasites infecting horses [66]. These so-called "small strongyles" show a high degree of resistance against benzimidazole anthelminthics and may lead to severe equine enteropathy, colic and death [146]. The study examined several species belonging to the cyathostomin helminths 


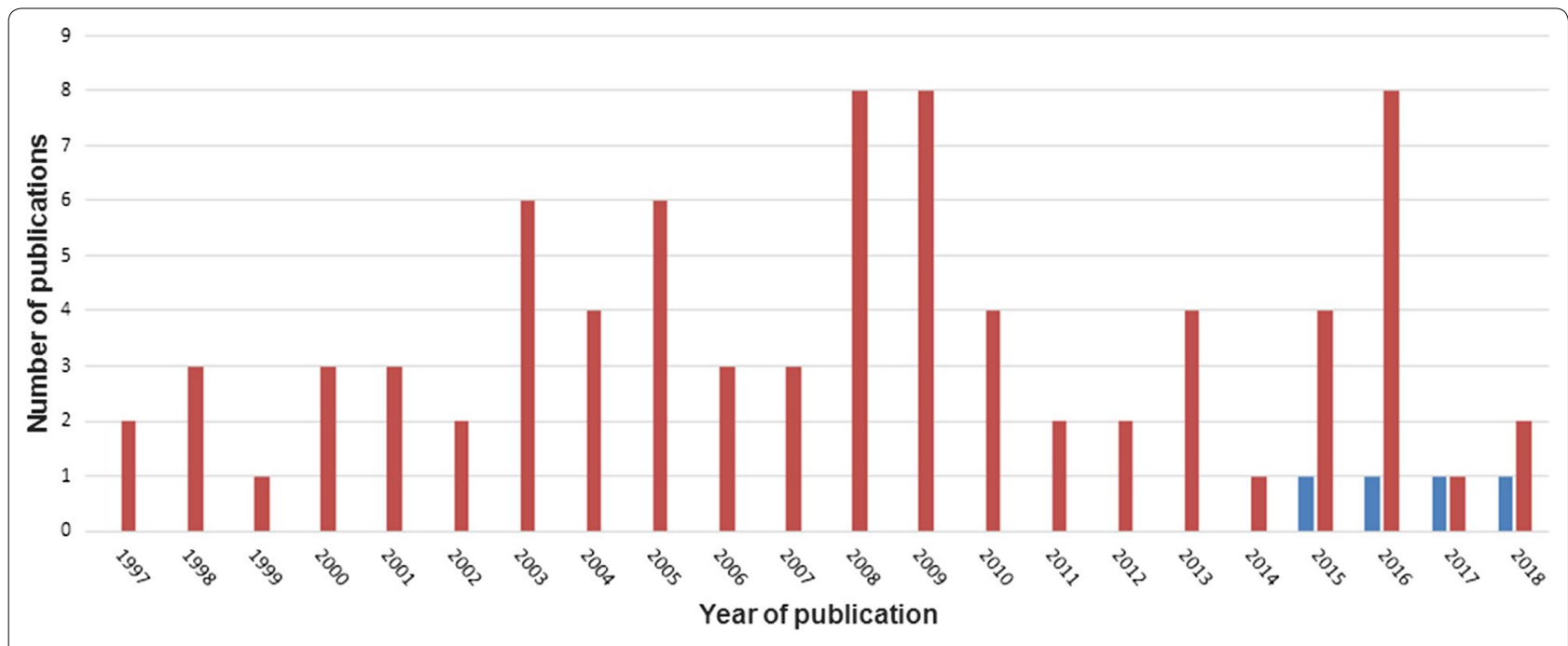

-Helminth $\quad$ Pathogen-specific molecules

Fig. 2 Publications in the peer-reviewed literature pertaining to the application of MALDI-TOF mass spectrometry for identification of helminths or specific pathogen-related components, as revealed by a systematic review, stratified by year of publication

(e.g. Coronocyclus coronatus, C. labiatus and C. labratus) and found distinct protein spectra among adult helminths of different species [66]. These findings were recently confirmed and substantiated by another study on the application of MALDI-TOF for differentiation of cyathostomins, which was published in April 2019 [147].

\section{Discussion}

We systematically reviewed the available literature pertaining to the application of MALDI-TOF MS for identification of helminthic pathogens of human and veterinary importance. While the technique has been successfully employed for many major classes of pathogens (e.g. bacteria, mycobacteria and fungi), data on its use in diagnostic helminthology are scarce. Several studies reported on the differential analysis of specific components, such as proteins, peptides or lipids with MALDI-TOF MS techniques, but only two recent manuscripts and one conference abstract provided 'proof-of-concept' evidence of its potential utility in diagnosing and differentiating helminth species of medical or veterinary relevance.

The majority of articles identified in this systematic review focused on protein-centred analyses of helminth samples. It is important to mention that some of the MALDI-TOF MS devices employed in these studies had been subjected to modifications that are not usually available in routine clinical laboratories. Additionally, these experiments frequently employed a complex sample pretreatment comprising a protein separation by high pressure liquid chromatography (HPLC) or electrophoresis. Yet, some recent proof-of-concept studies have shown that MALDI-TOF MS is also capable of diagnosing entire helminthic pathogens and differentiating similar species within the same genus based on an analysis of their individual protein spectra $[66,67]$. Because no helminths are currently included in commercially available MALDITOF MS identification databases, individual in-house databases need to be created through generation of main spectra libraries, ideally following established guidelines and protocols that are similar to those employed by the manufacturers of commercially available mass spectrometers [148]. Indeed, previous studies have described the sensitive, reliable and highly reproducible identification of helminths that cause plant infections and have concluded that MALDI-TOF MS should be more widely employed as a 'rapid detection tool' [54-58]. Ahmad et al. [56], for example, reported on the suitability of MALDITOF MS to differentiate harmless and juvenile infective stages of single plant nematodes, as these showed unique, characteristic protein peak patterns. These studies should be considered as relevant because plant-parasitic nematodes can sometimes also be found in human stool samples [149, 150]. In Brazil, for example, eggs of the root-knot nematode Meloidogyne spp. were detected in human faeces using a microscopic sedimentation method [151]. Future studies should also employ MALDI-TOF on serum, as a recent study reported the detection of specific proteins in serum of mice infected with Schistosoma japonicum [50].

While helminth infections pose a considerable burden on human and animal health [152], an accurate diagnosis of these conditions is frequently challenging. Indeed, 
simple diagnostic tools such as stool microscopy for soiltransmitted helminth infections are of limited value if the infection intensity is low and highly sensitive diagnostic techniques such as PCR-based assays are only available in selected reference laboratories outside endemic areas [153]. In high-income countries, in contrast, knowledge regarding standard diagnostic parasitology is waning and differentiation of closely related helminth species based on their microscopic morphology requires skilled laboratory technicians [154]. Moreover, some infections cannot be reliably distinguished with standard diagnostic techniques. A prominent example are infections caused by cestodes of the genus Taenia [155], which may cause a relatively harmless intestinal infection if cysts of Taenia saginata or T. solium are orally ingested with meat of cattle or pig. While eggs of $T$. saginata are not infectious to humans, T. solium eggs can lead to the potentially fatal disease (neuro-)cysticercosis. While the correct diagnosis has important implications for treatment, patient management and potential contact screening (intestinal carriage of adult $T$. solium worms poses an increased risk of cysticercosis for close contacts, such as family members), it is impossible to distinguish both species based on the identical morphology of their eggs under a microscope. Molecular tools can achieve an accurate differentiation of the two species, but are only available in research settings [155-157]. Sometimes, proglottids of adult worms are also passed in the faeces. While a distinct differentiation is possible based on the uterine branches within a proglottid, misidentification using this approach has been reported in clinical practice [158]. Hence, achieving a species-specific differentiation based on MALDITOF MS would contribute to an enhanced, more reliable identification, and future studies should thus address this issue. Similar considerations hold also true for other infective agents that can hardly be differentiated by other methods (e.g. different Echinococcus species), novel species (e.g. hybrid species of Schistosoma spp., which have recently been reported from Corsica, France [159]) and notoriously difficult-to-detect infections (e.g. strongyloidiasis). An overview of pathogens for which development of MALDI-TOF MS identification protocols would appear particularly promising is summarized in Table 1.

It is important to consider the fixative in which a parasitological sample is stored. Both formaldehyde and ethanol are commonly used to enable a long-term storage of biological specimens, but this may lead to profound changes of the protein structure [160], which is likely to influence on the results of MALDI-TOF examinations carried out on such samples. The virtual impossibility to amplify nucleic acids from formaldehyde-containing solutions [161] due to fragmentation of the single components [162] renders most PCR tests useless on these sample types, but MALDI-TOF analyses of protein spectra might still be possible, albeit with different spectra if compared to native samples. Hence, future studies should evaluate this technique on different kinds of fixatives and on samples that have been stored for prolonged periods.

The present review identified only a few successful studies that employed MALDI-TOF MS to diagnose helminths. Limitations include the complicated pretreatment procedures employed in some studies and the rather incomplete data presentation in one of the more clinically oriented research projects [65]. New research is needed to determine whether this technique might become a clinically meaningful addendum to the current set of diagnostic options. However, experiences made in clinical bacteriology, mycobacteriology, mycology as well as with ectoparasites (e.g. ticks) and vectors (e.g. mosquitoes) $[12,37,163]$ are promising. Whereas MALDI-TOF MS is mainly used on culture-grown colonies for identification of bacteria and mycobacteria, the goal in helminthology will be to provide a species-specific diagnosis based on either macroscopic elements or eggs and larvae that are present in stool samples (or other body fluids and tissue samples). Hence, specific protocols will need to be elaborated to this end, which may include sample preparation, purification and concentration steps, including guidance on the most appropriate sample preservation. However, such protocols have been successfully developed in the past (e.g. for identification of mycobacteria or moulds) $[164,165]$. More recently, specific pre-treatment modifications have even allowed to apply MALDITOF MS on blood culture broths [166] and fresh urine samples for direct identification of bacteria [167]. Additionally, detection of parasites in complex samples (e.g. blood), should be considered (e.g. as an antigen test for Wuchereria bancrofti [168] or for the detection of specific serum peptides [169]).

Yet, much research and rigorous validation is still needed before MALDI-TOF MS might be employed directly on stool samples, and priority should thus be given to (i) the establishment of in-house main spectra library databases to allow for species-specific identification of selected helminths; (ii) the subsequent development of sample treatment protocols; (iii) the validation of this technique on different clinical sample types; and (iv) the elaboration of MALDI-TOF MS to be employed on fixed samples.

\section{Conclusions}

The present systematic review elucidated that MALDITOF MS, which is now routinely used in many clinical microbiology laboratories for identification of bacteria, fungi and mycobacteria, could potentially also be employed in the context of helminth diagnosis. 


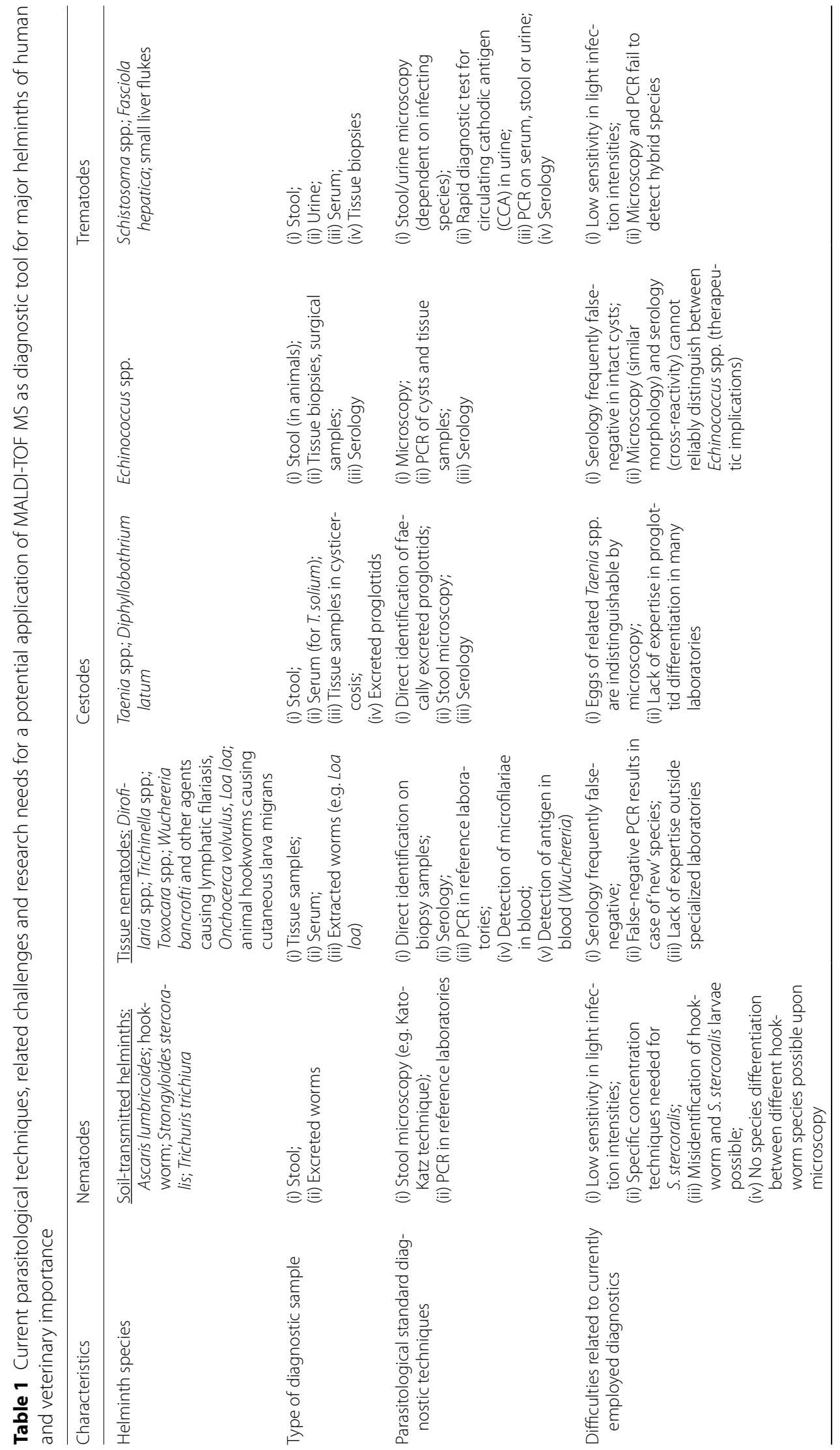




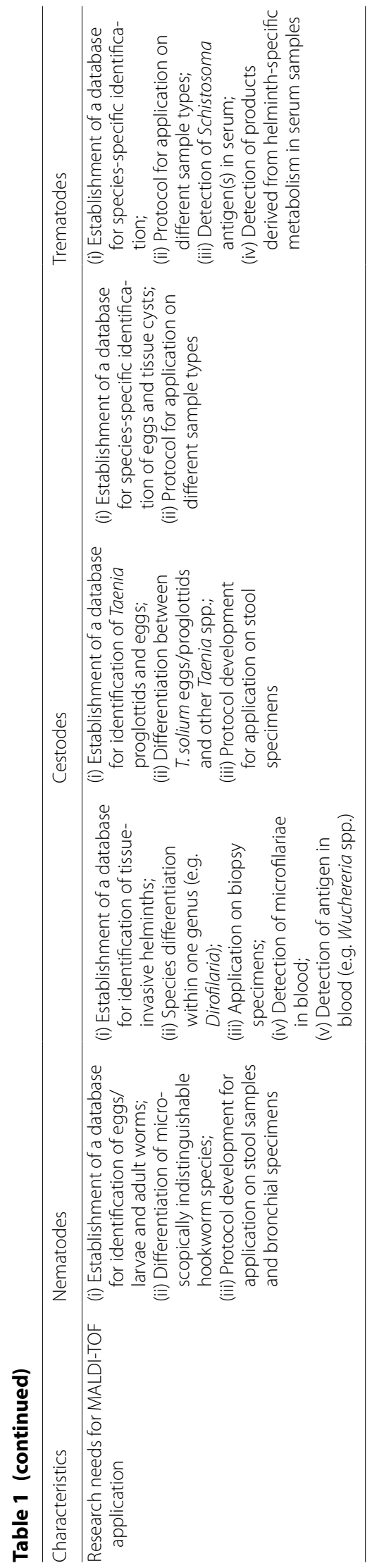


Preliminary data suggest that MALDI-TOF MS might hold promise as a future diagnostic tool for direct and rapid identification of pathogenic helminths in clinical samples with sufficient diagnostic accuracy. Further studies are needed to evaluate these concepts and to develop specific databases for helminth identification, followed by rigorous validation on well characterised clinical specimens.

\section{Additional files}

Additional file 1. Search strategies employed for our systematic review pertaining to the application of MALDI-TOF mass spectrometry as a diagnostic tool in human and veterinary helminthology.

Additional file 2. PRISMA checklist for a systematic review examining the application of MALDI-TOF mass spectrometry as potential tool in diagnostic human and veterinary helminthology.

Additional file 3. List of references included in the final review $(n=84$ articles).

\section{Abbreviations}

DALY: disability-adjusted life year; GBD: Global Burden of Disease (Study); MALDI-TOF: matrix-assisted laser desorption/ionization time-of-flight mass spectrometry; MS: mass spectrometry; PCR: Polymerase chain reaction.

\section{Acknowledgements}

Not applicable.

\section{Authors' contributions}

MF conducted the systematic review of the literature and extracted data. MF and SLB independently assessed published articles for eligibility, analysed and discussed data and drafted the first version of the manuscript. SP and JU contributed to data interpretation and revised the manuscript. All authors read and approved the final manuscript.

\section{Funding}

This systematic review received financial support from the 'Landesforschungsförderprogramm des Saarlandes'.

\section{Availability of data and materials}

The search strategy and all manuscripts included in this systematic review are available within the article and its additional files.

\section{Ethics approval and consent to participate}

Not applicable.

\section{Consent for publication}

Not applicable.

\section{Competing interests}

The authors declare that they have no competing interests.

\section{Author details}

${ }^{1}$ Institute of Medical Microbiology and Hygiene, Saarland University, Homburg/Saar, Germany. ${ }^{2}$ Luxembourg Institute of Science and Technology, Environmental Research and Innovation, Belvaux, Luxembourg. ${ }^{3}$ Swiss Tropical and Public Health Institute, Basel, Switzerland. ${ }^{4}$ University of Basel, Basel, Switzerland.

Received: 5 February 2019 Accepted: 6 May 2019

Published online: 17 May 2019

\section{References}

1. Tanaka K, Waki H, Ido Y, Akita S, Yoshida Y, Yoshida T, et al. Protein and polymer analyses up to m/z 100000 by laser ionization time-of-flight mass spectrometry. Rapid Commun Mass Spectrom. 1988;2:151-3.

2. Marvin LF, Roberts MA, Fay LB. Matrix-assisted laser desorption/ionization time-of-flight mass spectrometry in clinical chemistry. Clin Chim Acta. 2003:337:11-21.

3. Rees-Unwin KS, Morgan GJ, Davies FE. Proteomics and the haematologist. Clin Lab Haematol. 2004;26:77-86.

4. Anhalt JP, Fenselau C. Identification of bacteria using mass spectrometry techniques. Anal Chem. 1975;47:219-25.

5. Clark AE, Kaleta EJ, Arora A, Wolk DM. Matrix-assisted laser desorption ionization-time of flight mass spectrometry: a fundamental shift in the routine practice of clinical microbiology. Clin Microbiol Rev. 2013;26:547-603.

6. Carbonnelle E, Mesquita C, Bille E, Day N, Dauphin B, Beretti JL, et al. MALDI-TOF mass spectrometry tools for bacterial identification in clinical microbiology laboratory. Clin Biochem. 2011;44:104-9.

7. Singhal N, Kumar M, Kanaujia PK, Virdi JS. MALDI-TOF mass spectrometry: an emerging technology for microbial identification and diagnosis. Front Microbiol. 2015;6:791.

8. Angeletti S. Matrix assisted laser desorption time of flight mass spectrometry (MALDI-TOF MS) in clinical microbiology. J Microbiol Methods. 2017;138:20-9.

9. El Khéchine A, Couderc C, Flaudrops C, Raoult D, Drancourt M. Matrix assisted laser desorption/ionization time-of-flight mass spectrometry identification of mycobacteria in routine clinical practice. PLoS One. 2011;6:e24720.

10. Sjöholm MIL, Dillner J, Carlson J. Multiplex detection of human herpesviruses from archival specimens by using matrix-assisted laser desorption ionization-time of flight mass spectrometry. J Clin Microbiol. 2008:46:540-5

11. Yssouf A, Almeras L, Raoult D, Parola P. Emerging tools for identification of arthropod vectors. Future Microbiol. 2016;11:549-66.

12. Vega-Rúa A, Pagès N, Fontaine A, Nuccio C, Hery L, Goindin D, et al. Improvement of mosquito identification by MALDI-TOF MS biotyping using protein signatures from two body parts. Parasit Vectors. 2018:11:574.

13. Faron ML, Buchan BW, Hyke J, Madisen N, Lillie JL, Granato PA, et al. Multicenter evaluation of the Bruker MALDI Biotyper CA System for the identification of clinical aerobic gram-negative bacterial isolates. PLoS One. 2015:10:e0141350

14. Luo Y, Siu GKH, Yeung ASF, Chen JHK, Ho PL, Leung KW, et al. Performance of the VITEK MS matrix-assisted laser desorption ionization-time of flight mass spectrometry system for rapid bacterial identification in two diagnostic centres in China. J Med Microbiol. 2015;64:18-24.

15. Fall B, Lo Cl, Samb-Ba B, Perrot N, Diawara S, Gueye MW, et al. The ongoing revolution of MALDI-TOF mass spectrometry for microbiology reaches tropical Africa. Am J Trop Med Hyg. 2015;92:641-7.

16. Lo Cl, Fall B, Sambe-Ba B, Flaudrops C, Faye N, Mediannikov O, et al. Value of matrix assisted laser desorption ionization-time of flight (MALDI-TOF) mass spectrometry in clinical microbiology and infectious diseases in Africa and tropical areas. Afr J Microbiol Res. 2017;11:1360-70

17. Diongue K, Kébé O, Faye MD, Samb D, Diallo MA, Ndiaye M, et al. MALDI-TOF MS identification of Malassezia species isolated from patients with pityriasis versicolor at the Seafarers' Medical Service in Dakar, Senegal. J Mycol Med. 2018;28:590-3.

18. Taverna CG, Mazza M, Bueno NS, Alvarez C, Amigot S, Andreani M, et al. Development and validation of an extended database for yeast identification by MALDI-TOF MS in Argentina. Med Mycol. 2019;57:215-25.

19. Chabriere $E$, Bassène $H$, Drancourt M, Sokhna C. MALDI-TOF-MS and point of care are disruptive diagnostic tools in Africa. New Microbes New Infect. 2018;26:S83-8.

20. Yang Y, Lin Y, Qiao L. Direct MALDI-TOF MS identification of bacterial mixtures. Anal Chem. 2018:90:10400-8.

21. Ferreira L, Sánchez-Juanes F, González-Avila M, Cembrero-Fuciños D, Herrero-Hernández A, González-Buitrago JM, et al. Direct identification of urinary tract pathogens from urine samples by matrix-assisted laser desorption ionization-time of flight mass spectrometry. J Clin Microbiol. 2010:48:2110-5. 
22. Íñigo M, Coello A, Fernández-Rivas G, Rivaya B, Hidalgo J, Quesada $M D$, et al. Direct identification of urinary tract pathogens from urine samples, combining urine screening methods and matrix-assisted laser desorption ionization-time of flight mass spectrometry. J Clin Microbiol. 2016:54:988-93.

23. Singhal N, Kumar M, Virdi JS. MALDI-TOF MS in clinical parasitology: applications, constraints and prospects. Parasitology. 2016;143:1491-500.

24. Cassagne C, Pratlong F, Jeddi F, Benikhlef R, Aoun K, Normand A-C, et al. Identification of Leishmania at the species level with matrix-assisted laser desorption ionization time-of-flight mass spectrometry. Clin Microbiol Infect. 2014;20:551-7.

25. Culha G, Akyar I, Yildiz Zeyrek F, Kurt Ö, Gündüz C, Özensoy Töz S, et al. Leishmaniasis in Turkey: determination of Leishmania species by matrixassisted laser desorption ionization time-of-flight mass spectrometry (MALDI-TOF MS). Iran J Parasitol. 2014;9:239-48.

26. Lachaud L, Fernández-Arévalo A, Normand AC, Lami P, Nabet C, Donnadieu JL, et al. Identification of Leishmania by MALDI-TOF mass spectrometry using a free web-based application and a dedicated mass spectral library. J Clin Microbiol. 2017;55:2914-33.

27. Villegas EN, Glassmeyer ST, Ware MW, Hayes SL, Schaeffer FW. Matrixassisted laser desorption/ionization time-of-flight mass spectrometrybased analysis of Giardia lamblia and Giardia muris. J Eukaryot Microbiol. 2006;53:S179-81.

28. Magnuson ML, Owens JH, Kelty CA. Characterization of Cryptosporidium parvum by matrix-assisted laser desorption ionization-time of flight mass spectrometry. Appl Environ Microbiol. 2000;66:4720-4.

29. Avila CC, Almeida FG, Palmisano G. Direct identification of trypanosomatids by matrix-assisted laser desorption ionization-time of flight mass spectrometry (DIT MALDI-TOF MS). J Mass Spectrom. 2016:51:549-57.

30. Marks F, Meyer CG, Sievertsen J, Timmann C, Evans J, Horstmann RD, et al. Genotyping of Plasmodium falciparum pyrimethamine resistance by matrix-assisted laser desorption-ionization time-of-flight mass spectrometry. Antimicrob Agents Chemother. 2004:48:466-72.

31. Gitau EN, Kokwaro GO, Newton CR, Ward SA. Global proteomic analysis of plasma from mice infected with Plasmodium berghei ANKA using two dimensional gel electrophoresis and matrix assisted laser desorption ionization-time of flight mass spectrometry. Malar J. 2011;10:205.

32. de Dios Caballero J, Martin O. Application of MALDI-TOF in parasitology. In: Cobo F, editor. The use of mass spectrometry technology (MALDITOF) in clinical microbiology. London: Elsevier Inc: 2018. p. 235-53.

33. Calderaro A, Buttrini M, Montecchini S, Rossi S, Piccolo G, Arcangeletti MC, et al. MALDI-TOF MS as a new tool for the identification of Dientamoeba fragilis. Parasit Vectors. 2018;11:11.

34. Karger A, Kampen H, Bettin B, Dautel H, Ziller M, Hoffmann B, et al. Species determination and characterization of developmental stages of ticks by whole-animal matrix-assisted laser desorption/ionization mass spectrometry. Ticks Tick Borne Dis. 2011;3:78-89.

35. Yssouf A, Flaudrops C, Drali R, Kernif T, Socolovschi C, Berenger JM, et al. Matrix-assisted laser desorption ionization-time of flight mass spectrometry for rapid identification of tick vectors. J Clin Microbiol. 2013:51:522-8.

36. Diarra AZ, Almeras L, Laroche $M$, Berenger J-M, Koné AK, Bocoum Z, et al. Molecular and MALDI-TOF identification of ticks and tick-associated bacteria in Mali. PLoS Negl Trop Dis. 2017;11:e0005762.

37. Dib L, Benakhla A, Raoult D, Parola P. MALDI-TOF MS identification of ticks of domestic and wild animals in Algeria and molecular detection of associated microorganisms. Comp Immunol Microbiol Infect Dis. 2018:57:39-49.

38. Dvorak V, Halada P, Hlavackova K, Dokianakis E, Antoniou M, Volf P. Identification of phlebotomine sand flies (Diptera: Psychodidae) by matrixassisted laser desorption/ionization time of flight mass spectrometry. Parasit Vectors. 2014;7:21.

39. Yssouf A, Socolovschi C, Leulmi H, Kernif T, Bitam I, Audoly G, et al. Identification of flea species using MALDI-TOF/MS. Comp Immunol Microbiol Infect Dis. 2014;37:153-7.

40. Lafri I, Almeras L, Bitam I, Caputo A, Yssouf A, Forestier C-L, et al. Identification of Algerian field-caught phlebotomine sand fly vectors by MALDI-TOF MS. PLOS NegI Trop Dis. 2016;10:e0004351.
41. El Hamzaoui B, Laroche M, Almeras L, Bérenger J-M, Raoult D, Parola P. Detection of Bartonella spp. in fleas by MALDI-TOF MS. PLOS NegI Trop Dis. 2018;12:e0006189.

42. Dieme C, Yssouf A, Vega-Rúa A, Berenger JM, Failloux AB, Raoult D, et al. Accurate identification of Culicidae at aquatic developmental stages by MALDI-TOF MS profiling. Parasit Vectors. 2014;7:544.

43. Yssouf A, Parola P, Lindström A, Lilja T, L'Ambert G, Bondesson U, et al. Identification of European mosquito species by MALDI-TOF MS. Parasitol Res. 2014;113:2375-8.

44. Niare S, Berenger J-M, Dieme C, Doumbo O, Raoult D, Parola P, et al. Identification of blood meal sources in the main African malaria mosquito vector by MALDI-TOF MS. Malar J. 2016;15:87.

45. Tandina F, Almeras L, Koné AK, Doumbo OK, Raoult D, Parola P. Use of MALDI-TOF MS and culturomics to identify mosquitoes and their midgut microbiota. Parasit Vectors. 2016;9:495.

46. Raharimalala FN, Andrianinarivomanana TM, Rakotondrasoa A, Collard JM, Boyer S. Usefulness and accuracy of MALDI-TOF mass spectrometry as a supplementary tool to identify mosquito vector species and to invest in development of international database. Med Vet Entomol. 2017;31:289-98.

47. Tahir D, Almeras L, Varloud M, Raoult D, Davoust B, Parola P. Assessment of MALDI-TOF mass spectrometry for filariae detection in Aedes aegypti mosquitoes. PLoS Negl Trop Dis. 2017;11:e0006093.

48. Niare S, Tandina F, Davoust B, Doumbo O, Raoult D, Parola P, et al. Accurate identification of Anopheles gambiae Giles trophic preferences by MALDI-TOF MS. Infect Genet Evol. 2018;63:410-9.

49. Tandina F, Laroche M, Davoust B, Doumbo OK, Parola P. Blood meal identification in the cryptic species Anopheles gambiae and Anopheles coluzzii using MALDI-TOF MS. Parasite. 2018;25:40.

50. Huang Y, Li W, Liu K, Xiong C, Cao P, Tao J. New detection method in experimental mice for schistosomiasis: ClinProTool and matrix-assisted laser desorption/ionization time-of-flight mass spectrometry. Parasitol Res. 2016;115:4173-81.

51. Hotez PJ, Brindley PJ, Bethony JM, King CH, Pearce EJ, Jacobson J. Helminth infections: the great neglected tropical diseases. J Clin Invest. 2008;118:1311-21.

52. GBD 2017 DALYs, HALE Collaborators. Global, regional, and national disability-adjusted life-years (DALYs) for 359 diseases and injuries and healthy life expectancy (HALE) for 195 countries and territories, 19902017: a systematic analysis for the Global Burden of Disease Study 2017. Lancet. 2018;392:1859-922.

53. Calvo E, Flores-Romero P, López JA, Navas A. Identification of proteins expressing differences among isolates of Meloidogyne spp. (Nematoda: Meloidogynidae) by nano-liquid chromatography coupled to ion-trap mass spectrometry. J Proteome Res. 2005;4:1017-21.

54. Perera MR, Vanstone VA, Jones MGK. A novel approach to identify plant parasitic nematodes using matrix-assisted laser desorption ionization time-of-flight mass spectrometry. Rapid Commun Mass Spectrom. 2005;19:1454-60.

55. Ahmad F, Babalola OO, Tak HI. Potential of MALDI-TOF mass spectrometry as a rapid detection technique in plant pathology: identification of plant-associated microorganisms. Anal Bioanal Chem. 2012:404:1247-55.

56. Ahmad F, Gopal J, Wu H. Rapid and highly sensitive detection of single nematode via direct MALDI mass spectrometry. Talanta. 2012;93:182-5

57. Ahmad F, Babalola OO. Application of mass spectrometry as rapid detection tool in plant nematology. Appl Spectrosc Rev. 2014;49:1-10.

58. Ahmad F, Babalola OO, Wu H-F. Potential of MALDI-TOF mass spectrometry as a detection tool to identify plant-parasitic nematodes. J Nematol. 2014;46:132

59. Moher D, Liberati A, Tetzlaff J, Altman DG, The PRISMA Group. Preferred reporting items for systematic reviews and meta-analyses: the PRISMA statement. J Clin Epidemiol. 2009;62:1006-12.

60. Yergey AL, Coorssen JR, Backlund PS, Blank PS, Humphrey GA, Zimmerberg J, et al. De novo sequencing of peptides using MALDI/TOF-TOF. J Am Soc Mass Spectrom. 2002;13:784-91.

61. Rush MD, Rue EA, Wong A, Kowalski P, Glinski JA, van Breemen RB. Rapid determination of procyanidins using MALDI-TOF/TOF mass spectrometry. J Agric Food Chem. 2018;66:11355-61. 
62. Zhan L, Xie X, Li Y, Liu H, Xiong C, Nie Z. Differentiation and relative quantitation of disaccharide isomers by MALDI-TOF/TOF mass spectrometry. Anal Chem. 2018;90:1525-30.

63. Gerdt S, Lochnit G, Dennis RD, Geyer R. Isolation and structural analysis of three neutral glycosphingolipids from a mixed population of Caenorhabditis elegans (Nematoda: Rhabditida). Glycobiology. 1997;7:265-75.

64. Lochnit G, Dennis RD, Zähringer U, Geyer R. Structural analysis of neutral glycosphingolipids from Ascaris suum adults (Nematoda: Ascaridida). Glycoconj J. 1997;14:389-99.

65. Pshenichnaya N, Nagorny S, Aleshukina A, Ermakova L, Krivorotova E. Paper Poster Session II MALDI-TOF application of matrix-assisted laser desorption/ionization mass spectrometry for the identification of dirofilariasis species. 2015. In: Poster presentation at the 25th European Conference on Clinical Microbiology and Infectious Diseases (ECCMID) in Copenhagen, Denmark on 26 April 2015. https://www.escmid.org/ escmid_publications/escmid_elibrary/material/?mid=22817. Accessed 14 May 2019.

66. Bredtmann CM, Krücken J, Murugaiyan J, Kuzmina T, von SamsonHimmelstjerna G. Nematode species identification-current status, challenges and future perspectives for Cyathostomins. Front Cell Infect Microbiol. 2017;7:283.

67. Mayer-Scholl A, Murugaiyan J, Neumann J, Bahn P, Reckinger S, Nöckler K. Rapid identification of the foodborne pathogen Trichinella spp. by matrix-assisted laser desorption/ionization mass spectrometry. PLoS One. 2016;11:e0152062.

68. Marks NJ, Maule AG, Geary TG, Thompson DP, Li C, Halton DW, et al. KSAYMRFamide (PF3/AF8) is present in the free-living nematode, Caenorhabditis elegans. Biochem Biophys Res Commun. 1998;248:422-5.

69. Kaji H, Tsuji T, Mawuenyega KG, Wakamiya A, Taoka M, Isobe T. Profiling of Caenorhabditis elegans proteins using two-dimensional gel electrophoresis and matrix assisted laser desorption/ionization-time of flight mass spectrometry. Electrophoresis. 2000;21:1755-65.

70. Husson SJ, Clynen E, Baggerman G, Janssen T, Schoofs L. Defective processing of neuropeptide precursors in Caenorhabditis elegans lacking proprotein convertase 2 (KPC-2/EGL-3): mutant analysis by mass spectrometry. J Neurochem. 2006;98:1999-2012.

71. Ghaleb AM, Atwood J, Morales-Montor J, Damian RT. A 3 kDa peptide is involved in the chemoattraction in vitro of the male Schistosoma mansoni to the female. Microbes Infect. 2006;8:2367-75.

72. Yew JY, Davis R, Dikler S, Nanda J, Reinders B, Stretton AO. Peptide products of the afp- 6 gene of the nematode Ascaris suum have different biological actions. J Comp Neurol. 2007;502:872-82.

73. Nagano I, Wu Z, Takahashi Y. Functional genes and proteins of Trichinella spp. Parasitol Res. 2009;104:197-207.

74. Husson SJ, Landuyt B, Nys T, Baggerman G, Boonen K, Clynen E, et al. Comparative peptidomics of Caenorhabditis elegans versus C. briggsae by LC-MALDI-TOF MS. Peptides. 2009;30:449-57.

75. WeinkopffT, Atwood JA, Punkosdy GA, Moss D, Weatherly DB, Orlando $R$, et al. Identification of antigenic Brugia adult worm proteins by peptide mass fingerprinting. J Parasitol. 2009;95:1429-35.

76. Husson SJ, Clynen E, Boonen K, Janssen T, Lindemans M, Baggerman G, et al. Approaches to identify endogenous peptides in the soil nematode Caenorhabditis elegans. Methods Mol Biol. 2010;615:29-47.

77. Laschuk A, Monteiro KM, Vidal NM, Pinto PM, Duran R, Cerveñanski C, et al. Proteomic survey of the cestode Mesocestoides corti during the first 24 hours of strobilar development. Parasitol Res. 2011;108:645-56.

78. Rai R, Singh N, Elesela S, Tiwari S, Rathaur S. MALDI mass sequencing and biochemical characterization of Setaria cervi protein tyrosine phosphatase. Parasitol Res. 2013;112:147-54.

79. Konop CJ, Knickelbine JJ, Sygulla MS, Vestling MM, Stretton AOW. Different neuropeptides are expressed in different functional subsets of cholinergic excitatory motorneurons in the nematode Ascaris suum. ACS Chem Neurosci. 2015;6:855-70.

80. Marks NJ, Shaw C, Halton DW, Thompson DP, Geary TG, Li C, et al. Isolation and preliminary biological assessment of AADGAPLIRFamide and SVPGVLRFamide from Caenorhabditis elegans. Biochem Biophys Res Commun. 2001;286:1170-6.

81. Konop CJ, Knickelbine JJ, Sygulla MS, Wruck CD, Vestling MM, Stretton AOW. Mass spectrometry of single GABAergic somatic motorneurons identifies a novel inhibitory peptide, As-NLP-22, in the nematode Ascaris suum. J Am Soc Mass Spectrom. 2015;26:2009-23.
82. Mádi A, Mikkat S, Ringel B, Thiesen HJ, Glocker MO. Profiling stagedependent changes of protein expression in Caenorhabditis elegans by mass spectrometric proteome analysis leads to the identification of stage-specific marker proteins. Electrophoresis. 2003;24:1809-17.

83. Yatsuda AP, Krijgsveld J, Cornelissen AWCA, Heck AJR, De Vries E. Comprehensive analysis of the secreted proteins of the parasite Haemonchus contortus reveals extensive sequence variation and differential immune recognition. J Biol Chem. 2003;278:16941-51.

84. Vepřek P, Ježek J, Velek J, Tallima H, Montash M, El Ridi R. Peptides and multiple antigen peptides from Schistosoma mansoni glyceraldehyde 3-phosphate dehydrogenase: preparation, immunogenicity and immunoprotective capacity in C57BL/6 mice. J Pept Sci. 2004;10:350-62.

85. Gare D, Boyd J, Connolly B. Developmental regulation and secretion of nematode-specific cysteine-glycine domain proteins in Trichinella spiralis. Mol Biochem Parasitol. 2004;134:257-66.

86. Yew JY, Kutz KK, Dikler S, Messinger L, Li L, Stretton AO. Mass spectrometric map of neuropeptide expression in Ascaris suum. J Comp Neurol. 2005;488:396-413.

87. Quinn GAP, Heymans R, Rondaj F, Shaw C, de Jong-Brink M. Schistosoma mansoni dermaseptin-like peptide: structural and functional characterization. J Parasitol. 2005;91:1340-51.

88. Robinson MW, Gare DC, Connolly B. Profiling excretory/secretory proteins of Trichinella spiralis muscle larvae by two-dimensional gel electrophoresis and mass spectrometry. Vet Parasitol. 2005;132:37-41.

89. Loukas A, Hintz M, Linder D, Mullin NP, Parkinson J, Tetteh KKA, et al. A family of secreted mucins from the parasitic nematode Toxocara canis bears diverse mucin domains but shares similar flanking six-cysteine repeat motifs. J Biol Chem. 2000;275:39600-7.

90. Yamauchi S, Higashitani N, Otani M, Higashitani A, Ogura T, Yamanaka K. Involvement of HMG-12 and CAR-1 in the cdc-48.1 expression of Caenorhabditis elegans. Dev Biol. 2008:318:348-59.

91. Monteiro KM, Zaha A, Ferreira HB. Recombinant subunits as tools for the structural and functional characterization of Echinococcus granulosus antigen B. Exp Parasitol. 2008;119:490-8.

92. Goldfinch GM, Smith WD, Imrie L, McLean K, Inglis NF, Pemberton AD. The proteome of gastric lymph in normal and nematode infected sheep. Proteomics. 2008;8:1909-18.

93. Ahmad R, Srivastava AK, Walter RD. Purification and biochemical characterization of cytosolic glutathione-S-transferase from filarial worms Setaria cervi. Comp Biochem Physiol B Biochem Mol Biol. 2008;151:237-45

94. Sahoo MK, Sisodia BS, Dixit S, Joseph SK, Gaur RL, Verma SK, et al. Immunization with inflammatory proteome of Brugia malayi adult worm induces a Th1/Th2-immune response and confers protection against the filarial infection. Vaccine. 2009;27:4263-71.

95. Yuan SS, Xing XM, Liu JJ, Huang QY, Yang SQ, Peng F. Screening and identification of differentially expressed proteins between adult female and male worms of Schistosoma japonicum. Zhonghua Yu Fang Yi Xue Za Zhi. 2009:43:695-9.

96. Pak JH, Moon JH, Hwang SJ, Cho SH, Seo SB, Kim TS. Proteomic analysis of differentially expressed proteins in human cholangiocarcinoma cells treated with Clonorchis sinensis excretory-secretory products. J Cell Biochem. 2009:108:1376-88.

97. Sanglas L, Aviles FX, Huber R, Gomis-Rüth FX, Arolas JL. Mammalian metallopeptidase inhibition at the defense barrier of Ascaris parasite. Proc Natl Acad Sci USA. 2009;106:1743-7.

98. Yan F, Xu L, Liu L, Yan R, Song X, Li X. Immunoproteomic analysis of whole proteins from male and female adult Haemonchus contortus. Vet J. 2010;185:174-9.

99. Jarecki JL, Andersen K, Konop CJ, Knickelbine JJ, Vestling MM, Stretton AO. Mapping neuropeptide expression by mass spectrometry in single dissected identified neurons from the dorsal ganglion of the nematode Ascaris suum. ACS Chem Neurosci. 2010;1:505-19.

100. Brophy PM, Jefferies JR. Proteomic identification of glutathione S-transferases from the model nematode Caenorhabditis elegans. Proteomics. 2001;1:1463-8.

101. Kawasaki I, Jeong MH, Shim YH. Regulation of sperm-specific proteins by IFE-1, a germline-specific homolog of elF4E, in C. elegans. Mol Cells. 2011;31:191-7.

102. Clegg RA, Bowen LC, Bicknell AV, Tabish M, Prescott MC, Rees HH, et al. Characterisation of the $\mathrm{N}^{\prime} 1$ isoform of the cyclic AMP-dependent 
protein kinase (PK-A) catalytic subunit in the nematode, Caenorhabditis elegans. Arch Biochem Biophys. 2012;519:38-45.

103. Millares P, LaCourse EJ, Perally S, Ward DA, Prescott MC, Hodgkinson $\mathrm{JE}$, et al. Proteomic profiling and protein identification by MALDI-TOF mass spectrometry in unsequenced parasitic nematodes. PLoS One. 2012;7:e33590.

104. Ondrovics M, Silbermayr K, Mitreva M, Young ND, Razzazi-Fazeli E, Gasser RB, et al. Proteomic analysis of Oesophagostomum dentatum (Nematoda) during larval transition, and the effects of hydrolase inhibitors on development. PLoS One. 2013;8:e63955.

105. Tian F, Hou M, Chen L, Gao Y, Zhang X, Ji M, et al. Proteomic analysis of schistosomiasis japonica vaccine candidate antigens recognized by UV-attenuated cercariae-immunized porcine serum IgG2. Parasitol Res. 2013;112:2791-803.

106. JebaMercy G, Durai S, Prithika U, Marudhupandiyan S, Dasauni P, Kundu $\mathrm{S}$, et al. Role of DAF-21 protein in Caenorhabditis elegans immunity against Proteus mirabilis infection. J Proteom. 2016;145:81-90.

107. Henze A, Homann T, Rohn I, Aschner M, Link CD, Kleuser B, et al. Caenorhabditis elegans as a model system to study post-translational modifications of human transthyretin. Sci Rep. 2016;6:37346.

108. Timm T, Grabitzki J, Severcan C, Muratoglu S, Ewald L, Yilmaz Y, et al. The PCome of Ascaris suum as a model system for intestinal nematodes: identification of phosphorylcholine-substituted proteins and first characterization of the PC-epitope structures. Parasitol Res. 2016;115:1263-74.

109. Wang $F, X u L$, Song $X, L i X$, Yan R. Identification of differentially expressed proteins between free-living and activated third-stage larvae of Haemonchus contortus. Vet Parasitol. 2016;215:72-7.

110. Mikeš L, Man P. Purification and characterization of a saccharide-binding protein from penetration glands of Diplostomum pseudospathaceum - a bifunctional molecule with cysteine protease activity. Parasitology. 2003;127:69-77.

111. Cheng G-F, Lin J-J, Feng X-G, Fu Z-Q, Jin Y-M, Yuan C-X, et al. Proteomic analysis of differentially expressed proteins between the male and female worm of Schistosoma japonicum after pairing. Proteomics. 2005:5:511-21.

112. Robinson MW, Connolly B. Proteomic analysis of the excretory-secretory proteins of the Trichinella spiralis L1 larva, a nematode parasite of skeletal muscle. Proteomics. 2005;5:4525-32.

113. Ahn DH, Singaravelu G, Lee S, Ahnn J, Shim YH. Functional and phenotypic relevance of differentially expressed proteins in calcineurin mutants of Caenorhabditis elegans. Proteomics. 2006:6:1340-50.

114. Grabitzki J, Ahrend M, Schachter H, Geyer R, Lochnit G. The PCome of Caenorhabditis elegans as a prototypic model system for parasitic nematodes: identification of phosphorylcholine-substituted proteins. Mol Biochem Parasitol. 2008;161:101-11.

115. Acosta D, Cancela M, Piacenza L, Roche L, Carmona C, Tort JF. Fasciola hepatica leucine aminopeptidase, a promising candidate for vaccination against ruminant fasciolosis. Mol Biochem Parasitol. 2008;158:52-64

116. Mádi A, Mikkat S, Koy C, Ringel B, Thiesen HJ, Glocker MO. Mass spectrometric proteome analysis suggests anaerobic shift in metabolism of Dauer larvae of Caenorhabditis elegans. Biochim Biophys Acta. 2008;1784:1763-70

117. Wuhrer M, Grimm C, Dennis RD, Idris MA, Geyer R. The parasitic trematode Fasciola hepatica exhibits mammalian-type glycolipids as well as Gal(B1-6)Gal-terminating glycolipids that account for cestode serological cross-reactivity. Glycobiology. 2004;14:115-26.

118. Mika A, Gołebiowski M, Szafranek J, Rokicki J, Stepnowski P. Identification of lipids in the cuticle of the parasitic nematode Anisakis simplex and the somatic tissues of the Atlantic cod Gadus morhua. Exp Parasitol. 2010;124:334-40.

119. Lochnit G, Nispel S, Dennis RD, Geyer R. Structural analysis and immunohistochemical localization of tow acidic glycosphingolipids from the porcine, parasitic nematode, Ascaris suum. Glycobiology. 1998;8:891-9.

120. Lochnit G, Dennis RD, Ulmer AJ, Geyer R. Structural elucidation and monokine-inducing activity of two biologically active zwitterionie glycosphingolipids derived from the porcine parasitic nematode Ascaris suum. J Biol Chem. 1998;273:466-74.

121. Gerdt S, Dennis RD, Borgonie G, Schnabel R, Geyer R. Isolation, characterization and immunolocalization of phosphorylcholine-substituted glycolipids in developmental stages of Caenorhabditis elegans. Eur J Biochem. 1999;266:952-63.

122. Wuhrer M, Rickhoff S, Dennis RD, Lochnit G, Soboslay PT, Baumeister S, et al. Phosphocholine-containing, zwitterionic glycosphingolipids of adult Onchocerca volvulus as highly conserved antigenic structures of parasitic nematodes. Biochem J. 2000;348(Pt2):417-23.

123. Wuhrer M, Berkefeld C, Dennis RD, Idris MA, Geyer R. The liver flukes Fasciola gigantica and Fasciola hepatica express the leucocyte cluster of differentiation marker CD77 (globotriaosylceramide) in their tegument. Biol Chem. 2001;382:195-207.

124. López-Marín LM, Montrozier H, Lemassu A, García E, Segura E, Daffé M. Structure and antigenicity of the major glycolipid from Taenia solium cysticerci. Mol Biochem Parasitol. 2002;1 19:33-42.

125. Iriko H, Nakamura K, Kojima H, lida-Tanaka N, Kasama T, Kawakami Y, et al. Chemical structures and immunolocalization of glycosphingolipids isolated from Diphyllobothrium hottai adult worms and plerocercoids. Eur J Biochem. 2002;269:3549-59.

126. Wuhrer M, Grimm C, Zähringer U, Dennis RD, Berkefeld CM, Idris MA, et al. A novel GlcNAca1-HPO3-6Gal(1-1)ceramide antigen and alkylated inositol-phosphoglycerolipids expressed by the liver fluke Fasciola hepatica. Glycobiology. 2003;13:129-37.

127. Friedl CH, Lochnit G, Zähringer U, Bahr U, Geyer R. Structural elucidation of zwitterionic carbohydrates derived from glycosphingolipids of the porcine parasitic nematode Ascaris suum. Biochem J. 2003;369:89-102.

128. Paschinger K, Rendić $\mathrm{D}$, Lochnit $\mathrm{G}$, Jantsch V, Wilson IBH. Molecular basis of anti-horseradish peroxidase staining in Caenorhabditis elegans. J Biol Chem. 2004;279:49588-98.

129. Paschinger K, Wilson IBH. Two types of galactosylated fucose motifs are present on N-glycans of Haemonchus contortus. Glycobiology. 2015;25:585-90.

130. Hewitson JP, Nguyen DL, van Diepen A, Smit CH, Koeleman CA McSorley $\mathrm{HJ}$, et al. Novel O-linked methylated glycan antigens decorate secreted immunodominant glycoproteins from the intestinal nematode Heligmosomoides polygyrus. Int J Parasitol. 2016;46:157-70.

131. Veríssimo CM, Morassutti AL, von Itzstein M, Sutov G, Hartley-Tassell L, McAtamney S, et al. Characterization of the N-glycans of female Angiostrongylus cantonensis worms. Exp Parasitol. 2016;166:137-43.

132. Paschinger $\mathrm{K}$, Wilson IBH. Analysis of zwitterionic and anionic N-linked glycans from invertebrates and protists by mass spectrometry. Glycoconj J. 2016;33:273-83.

133. Jiménez-Castells C, Vanbeselaere J, Kohlhuber S, Ruttkowski B, Joachim A, Paschinger K. Gender and developmental specific N-glycomes of the porcine parasite Oesophagostomum dentatum. Biochim Biophys Acta. 2017:1861:418-30.

134. Yan S, Wang H, Schachter $\mathrm{H}$, Jin C, Wilson IBH, Paschinger K. Ablation of $\mathrm{N}$-acetylglucosaminyltransferases in Caenorhabditis induces expression of unusual intersected and bisected N-glycans. Biochim Biophys Acta. 2018;1862:2191-203.

135. Yan S, Vanbeselaere J, Jin C, Blaukopf M, Wöls F, Wilson IBH, et al. Core richness of $\mathrm{N}$-glycans of Caenorhabditis elegans: a case study on chemical and enzymatic release. Anal Chem. 2018:90:928-35.

136. Cipollo JF, Awad AM, Costello CE, Hirschberg CB. N-glycans of Caenorhabditis elegans are specific to developmental stages. J Biol Chem. 2005;280:26063-72.

137. Robijn MLM, Koeleman CAM, Hokke CH, Deelder AM. Schistosoma mansoni eggs excrete specific free oligosaccharides that are detectable in the urine of the human host. Mol Biochem Parasitol. 2007;151:162-72.

138. Robijn MLM, Koeleman CAM, Wuhrer M, Royle L, Geyer R, Dwek RA, et al. Targeted identification of a unique glycan epitope of Schistosoma mansoni egg antigens using a diagnostic antibody. Mol Biochem Parasitol. 2007;151:148-61.

139. Kaneiwa T, Yamada S, Mizumoto S, Montaño AM, Mitani S, Sugahara K. Identification of a novel chondroitin hydrolase in Caenorhabditis elegans. J Biol Chem. 2008;283:14971-9.

140. Tefsen B, van Stijn CMW, van den Broek M, Kalay H, Knol JC, Jimenez $\mathrm{CR}$, et al. Chemoenzymatic synthesis of multivalent neoglycoconjugates carrying the helminth glycan antigen LDNF. Carbohydr Res. 2009:344:1501-7.

141. Borloo J, De Graef J, Peelaers I, Nguyen DL, Mitreva M, Devreese B, et al. In-depth proteomic and glycomic analysis of the adult-stage Cooperia oncophora excretome/secretome. J Proteome Res. 2013;12:3900-11. 
142. Parsons LM, Mizanur RM, Jankowska E, Hodgkin J, O'Rourke D, Stroud D, et al. Caenorhabditis elegans bacterial pathogen resistant bus-4 mutants produce altered mucins. PLoS One. 2014;9:e107250.

143. Yan S, Jin C, Wilson IBH, Paschinger K. Comparisons of Caenorhabditis fucosyltransferase mutants reveal a multiplicity of isomeric $\mathrm{N}$-glycan structures. J Proteome Res. 2015;14:5291-305.

144. Alim MA, Fu Y, Wu Z, Zhao S, Cao J. Single nucleotide polymorphisms of toll-like receptors and association with Haemonchus contortus infection in goats. Pak Vet J. 2016:36:286-91.

145. Nagorny SA, Aleshukina AV, Aleshukina IS, Ermakova LA, Pshenichnaya NY. The application of proteomic methods (MALDI-toff MS) for studying protein profiles of some nematodes (Dirofilaria and Ascaris) for differentiating species. Int J Infect Dis. 2019;S1201-9712(19):30113-4.

146. Lyons E, Tolliver S, Drudge J. Historical perspective of cyathostomes: prevalence, treatment and control programs. Vet Parasitol. 1999:85:97-112.

147. Bredtmann CM, Krücken J, Murugaiyan J, Balard A, Hofer H, Kuzmina TA, et al. Concurrent proteomic fingerprinting and molecular analysis of cyathostomins. Proteomics. 2019;19:e1800290.

148. To G, Maldi E, Table LT, Fume V, Eppendorf M, Analytical R, et al. Generating new MSP with Bruker Microflex LT. https://spectra.folkhalsomyndig heten.se/spectra/. Accessed 14 May 2019.

149. Yajima F, Kurono Y, Igarashi K, Uchida A, Ozeki Y. On the unknown nematoda eggs found in human stool which are confusing with the egg of human parasites. J Jpn Assoc Rural Med. 1959;8:57-61.

150. Bradbury RS, Speare R. Passage of Meloidogyne eggs in human stool: forgotten, but not gone. J Clin Microbiol. 2015;53:1458-9.

151. Santos FLN, de Souza AMGC, Dantas-Torres F. Meloidogyne eggs in human stool in Northeastern Brazil. Rev Soc Bras Med Trop. 2016:49:802

152. Utzinger J, Becker SL, Knopp S, Blum J, Neumayr AL, Keiser J, et al. Neglected tropical diseases: diagnosis, clinical management, treatment and control. Swiss Med Wkly. 2012;142:w13727.

153. Becker SL, Liwanag HJ, Snyder JS, Akogun O, Belizario V, Freeman MC, et al. Toward the $2020 \mathrm{goal}$ of soil-transmitted helminthiasis control and elimination. PLoS Negl Trop Dis. 2018;12:e0006606.

154. van Lieshout $L$, Roestenberg M. Clinical consequences of new diagnostic tools for intestinal parasites. Clin Microbiol Infect. 2015;21:520-8.

155. González LM, Montero E, Harrison LJS, Parkhouse RME, Garate T. Differential diagnosis of Taenia saginata and Taenia solium infection by PCR. J Clin Microbiol. 2000;38:737-44.

156. Flisser A, Viniegra A-E, Aguilar-Vega L, Garza-Rodriguez A, Maravilla P, Avila G. Portrait of human tapeworms. J Parasitol. 2004:90:914-6.

157. Mayta H, Gilman RH, Prendergast E, Castillo JP, Tinoco YO, Garcia HH, et al. Nested PCR for specific diagnosis of Taenia solium taeniasis. J Clin Microbiol. 2008;46:286-9.

158. Mayta H, Talley A, Gilman RH, Jimenez J, Verastegui M, Ruiz M, et al. Differentiating Taenia solium and Taenia saginata infections by simple hematoxylin-eosin staining and PCR-restriction enzyme analysis. J Clin Microbiol. 2000;38:133-7.

159. Boissier J, Grech-Angelini S, Webster BL, Allienne JF, Huyse T, Mas-Coma $\mathrm{S}$, et al. Outbreak of urogenital schistosomiasis in Corsica (France): an epidemiological case study. Lancet Infect Dis. 2016;16:971-9.

160. Klopfleisch R, Weiss ATA, Gruber AD. Excavation of a buried treasureDNA, mRNA, miRNA and protein analysis in formalin fixed, paraffin embedded tissues. Histol Histopathol. 2011;26:797-810.

161. Lehmann $U$, Kreipe $H$. Real-time PCR analysis of DNA and RNA extracted from formalin-fixed and paraffin-embedded biopsies. Methods. 2001:25:409-18.

162. Bonin S. PCR analysis in archival postmortem tissues. Mol Pathol. 2003:56:184-6.

163. Laroche M, Bérenger JM, Gazelle G, Blanchet D, Raoult D, Parola P. Corrigendum: MALDI-TOF MS protein profiling for the rapid identification of chagas disease triatomine vectors and application to the triatomine fauna of French Guiana. Parasitology. 2018;145:676.

164. Neuschlova M, Vladarova M, Kompanikova J, Sadlonova V, Novakova E. Identification of Mycobacterium species by MALDI-TOF mass spectrometry. Adv Exp Med Biol. 2017;1021:37-42.

165. Sanguinetti M, Posteraro B. Identification of molds by matrix-assisted laser desorption ionization-time of flight mass spectrometry. J Clin Microbiol. 2017;55:369-79.

166. Lagace-Wiens PRS, Adam HJ, Karlowsky JA, Nichol KA, Pang PF, Guenther J, et al. Identification of blood culture isolates directly from positive blood cultures by use of matrix-assisted laser desorption ionizationtime of flight mass spectrometry and a commercial extraction system: analysis of performance, cost, and turnaround time. J Clin Microbiol. 2012:50:3324-8.

167. Huang B, Zhang L, Zhang W, Liao K, Zhang S, Zhang Z, et al. Direct detection and identification of bacterial pathogens from urine with optimized specimen processing and enhanced testing algorithm. J Clin Microbiol. 2017:55:1488-95.

168. Steel C, Golden A, Kubofcik J, LaRue N, De los Santos T, Domingo GJ, et al. Rapid Wuchereria bancrofti-specific antigen Wb123-based lgG4 immunoassays as tools for surveillance following mass drug administration programs on lymphatic filariasis. Clin Vaccine Immunol. 2013;20:1155-61.

169. Sparbier K, Wenzel T, Dihazi H, Blaschke S, Müller GA, Deelder A, et al. Immuno-MALDI-TOF MS: new perspectives for clinical applications of mass spectrometry. Proteomics. 2009;9:1442-50.

\section{Publisher's Note}

Springer Nature remains neutral with regard to jurisdictional claims in published maps and institutional affiliations.
Ready to submit your research? Choose BMC and benefit from:

- fast, convenient online submission

- thorough peer review by experienced researchers in your field

- rapid publication on acceptance

- support for research data, including large and complex data types

- gold Open Access which fosters wider collaboration and increased citations

- maximum visibility for your research: over 100M website views per year

At $B M C$, research is always in progress.

Learn more biomedcentral.com/submissions 